\title{
Analysis of the socio-economic indicators of the Irkutsk region, Buryatia, and the Far East in 2016- 2017: investments and prospects
}

\author{
Lilia Rudykh ${ }^{1, *}$, and Olga Shilova ${ }^{2}$ \\ ${ }^{1}$ Irkutsk National Research Technical University, 664074, Lermontova str., 83, Irkutsk, Russia \\ ${ }^{2}$ Irkutsk State University, 664003, Karla Marksa str., 1, Irkutsk, Russia
}

\begin{abstract}
Socio-economic indicators of the Irkutsk region, Buryatia and the Far East, dynamics of their development in 2016-2017, and problems and prospects are considered in this paper. Today, the priority for the regions of Siberia and the Far East, which possess unique natural resources and a vast territory, is the complex task of increasing the living standard of the population and launching a new economic strategy. The Irkutsk region is one of the largest industrial regions of Russia. The city of Irkutsk was formed as an administrative, commercial and cultural-educational center. Currently, it is home to more than $50 \%$ of the urban population of the Irkutsk region. Some enterprises of the city have a machine-building profile. The production of food (more than $45 \%$ of the total volume), the construction material, and wood processing also play an important role. External migration has a significant impact on the demographic situation in the region. Most of the migration processes with the crossing of the boundaries of the region take place within Russia. According to statistical data, external migration can be divided as the three main flows of foreign citizens entering the territory of the Irkutsk region: - the Central Asian direction (Uzbekistan, Tajikistan, Kyrgyzstan, and Kazakhstan - 44.3\%); - the East Asian direction (China, Mongolia, DPRK, Japan, and Vietnam - 30.8\%); - and the Western direction (Germany, France, and Poland). It should be also noted that $13.9 \%$ of all migrants are migrants from Ukraine, Armenia, Belarus, and Moldova, these are mainly young people of working age. The Baikal region is famous in Russia for its natural landscapes: there are more than 1,500 objects of excursion and cognitive significance (natural, architectural, cultural and historical monuments) in the region. The region has a great industrial potential that is of national importance. Several basic complexes and industries compile a modern industrial structure. There are opportunities for further development of the industrial production in the oil and gas industries, diamond mining industry, the production of composite materials, fibers and mineral fertilizers. On the Far East, priority is given today to the raw material economy and the related infrastructure facilities, including the modernization of the Trans-Siberian Railway and the Baikal-Amur Mainline.
\end{abstract}

\footnotetext{
* Corresponding author: lili.rudih2011@ yandex.ru
} 


\section{Introduction}

The resource potential of the Siberian and Far Eastern territories has traditionally been considered as a competitive advantage for the whole of Russia. During the Soviet period, the development of these regions was the most important task of the state that was provided with huge state investments. The development of new oil, gas, ore, coal deposits, construction of the Baikal-Amur Railway Mainline line, a network of regional airports, and new cities took place. All this was accompanied by a massive influx of people. In the prerevolutionary period, Siberia and the Far East also developed as a single whole with the control center in Irkutsk, where the residence of the East Siberian Governor General was located, whose powers spread from Siberia to the Pacific Ocean.

\section{Materials and methods}

Currently, less than $10 \%$ of the population lives in the vast territories of these constituent entities of the Russian Federation. The population of the Russian Federation is 146,804,372.000 (according to the data of the Federal Statistics Service of the Russian Federation as of January 1, 2017). The population of the Irkutsk region is 2 million 412 thousand people; Buryatia - 982.3 thousand people; The Far Eastern Federal District (the Amur Region, the Jewish Autonomous Region, the Kamchatka Territory, the Magadan Region, the Primorskii Territory, the Sakhalin Region, the Khabarovsk Territory, the Chukotka Autonomous District, and the Republic of Sakha Yakutia) - 6 million 195 thousand people.

Siberia, Buryatia and the Far East will remain the territories of the country with a stable migration outflow without support of the federal programs of social and economic cooperation that ensure the economy, investment attractiveness and comfortable living environment for the residents of these regions.

The socio-economic indicators of these territories are quite contradictory. Comparatively good socio-economic indicators in some areas, with a number of, directly speaking, failures in other areas of activity over the past two years, are not accompanied by the major thing, namely - a real increase in the level of incomes and the quality of life of the population, which causes the spread of the depressed moods in society.

From the point of view of the economic indicators, the Irkutsk region was not bad in 2016-2017. In 2016 compared to 2015, the growth of the industrial production was $105.7 \%$, primarily due to the export-oriented industries. The Irkutsk Region outstripped the average Russian level by $4.6 \%$ that provided the fourth place in the Siberian Federal District [1]. As it is known, the index of the industrial production consists of 4 basic activities: mining, processing industries, electricity (gas and steam) and water supply (sewerage and waste management). If in some recent years, the industrial growth in the Irkutsk region has been ensured by mining, in the last two years the growth has been recorded in the processing industries, and in 2016 its index was 101.9\%. This applies to the timber industry, petrochemical and pharmaceutical industries.

In 2017, the gross regional product grew by $3.4 \%$, and in the last two years - by $9.2 \%$. The index of the industrial production was $104.7 \%$, which is $3.5 \%$ more than the average for Russia. In particular, according to the Statistics Agency of Irkutsk, the extraction of minerals in comparison with 2016 increased by $3.3 \%$, including metal ores - by $4.8 \%$, coal - by $4.6 \%$, crude oil and natural gas - by $2.6 \%$, and other minerals - by $20.2 \%$. 
Table 1. Dynamics of the main socio-economic indicators.

\begin{tabular}{|l|c|c|c|}
\hline \multicolumn{1}{|c|}{ Indicator } & $\begin{array}{c}\text { Irkutsk } \\
\text { region }\end{array}$ & $\begin{array}{c}\text { Siberian } \\
\text { federal } \\
\text { district }\end{array}$ & $\begin{array}{c}\text { Russian } \\
\text { Federation }\end{array}$ \\
\hline $\begin{array}{l}\text { Industrial production index } \\
10 \text { months 2017 as \% of 10 months 2016 }\end{array}$ & 105.7 & 103.0 & 101.6 \\
\hline $\begin{array}{l}\text { Index of industrial production in the mining } \\
\text { sector } \\
10 \text { months 2017 as \% of 10 months 2016 }\end{array}$ & 104.0 & 106.4 & 102.5 \\
\hline $\begin{array}{l}\text { Index of industrial production in manufacturing } \\
10 \text { months 2017 as \% of 10 months 2016 }\end{array}$ & 108.3 & 100.6 & 100.9 \\
\hline $\begin{array}{l}\text { Investments in fixed assets } \\
9 \text { months 2017 as \% of 9 months 2016 }\end{array}$ & 104.5 & 96.9 & 104.2 \\
\hline $\begin{array}{l}\text { Scope of work performed in construction } \\
10 \text { months 2017 as \% of 10 months 2016 }\end{array}$ & 126.5 & 95.1 & 97.9 \\
\hline $\begin{array}{l}\text { Construction of houses, } \\
10 \text { months 2017 as \% of 10 months 2016 }\end{array}$ & 142.8 & 87.9 & 95.7 \\
\hline $\begin{array}{l}\text { Average monthly nominal accrued wages } \\
\text { 9 months 2017 as \% of 9 months 2016 }\end{array}$ & 10.5 & 106.3 & 107.0 \\
\hline
\end{tabular}

In terms of the rates of the investment growth, the Irkutsk region got the first place in the Siberian Federal District and the eighth place in Russia. For 9 months of 2017, the growth in these indicators was $4.5 \%$ compared to the corresponding period of 2016, and a year earlier the volume of investments amounted to about 258.5 billion rubles, which is $22 \%$ more than in 2015.

Positive trends are largely related to the implementation of investment projects by the largest companies in the region, such as VChNG, NK Dulcima, INC Limited, ANKhK, and others. The implementation of major investment projects is continuing: the construction of the Power of Siberia gas pipeline, Gazprom, the small-scale production plant of Pharmsintez, the aluminum plant of Rusal in the city of Taishet, the production of polymer additives Baikal Bitumen Terminal Limited in the city of Angarsk. The growth of investments in the analyzed period was mainly due to the increased investments in such industries as electricity generation and distribution, mining, transport, and construction.

There is an increase in the tax revenues to the budget of the Irkutsk region. According to the Governor of the Irkutsk region Sergei Levchenko, complicated negotiations have been conducted over the past two years with large enterprises as taxpayers, which allowed increasing incomes to the regional budget. The volume of the tax revenues in 2016 amounted to 6.2 billion rubles that is $7.8 \%$ more than in 2015 [2].

The tourist activity is stably growing in the Irkutsk region. Only over the past five years, the tourist flow has grown by $56 \%$. This increase is an average of $8 \%$ per year. In 2012, the region visited 976 thousand tourists, in $2016-1.5$ million tourists. Of the 84.0 thousand foreign tourists, 36.9 thousand tourists arrived to the Irkutsk region from China. For 9 months of 2017 , the number of tourists increased by $21.2 \%$ and amounted to 11604 thousand people. On the number of travelers from abroad, in 2017 the Angara region moved to the sixth place among the Russian regions. There are 116 operators working in the region, and 439 accommodation facilities of different classification are registered. The amount of the tax revenues from tourist and recreational activities to the budget of the Irkutsk region amounted to $6,325,364$ thousand rubles (an average of $1 \%$ ).

Each Russian region has its own specifics in the socio-economic development. The Irkutsk region owes much in its investment appeal to the unique Lake of Baikal. In its waters, there are more than 2600 different kinds of plants and animals, some of them are listed in the 
Red Book. The depth of the lake is 1624 meters, and the water transparency is 40 meters deep.

The island of Olkhon is very popular among tourists. The largest on Lake Baikal, it is rightly considered not only a mystical place, but also famous for its diversity of landscapes. Vitim and Baikal nature reserves, taiga areas of Eastern Sayan and Khamar-Daban are also of interest for tourists.

All listed monuments of nature are of national importance and represent a cultural, aesthetic and scientific value.

The Irkutsk region has a favorable geographical position in terms of cooperation with China. Chinese investors show considerable interest in the reserved places of Lake Baikal. In 2016, the company Grand Baikal signed a memorandum with the Chinese side represented by the company Zhongjixin, in which the intention of investors from the PRC was announced to invest 11 billion dollars in the development of tourism infrastructure on Lake Baikal. The fact that the main flow of the Chinese tourists will pass through the National and Zabaikalskii parks covering half of the Baikal coasts, and the consequences of mass tourism not only does not guarantee the preservation of nature, but also contribute to its degradation, and the destruction of the unique natural landscapes is of serious concern.

The demographic factor is one of the most important indicators from the point of view of territorial development. According to the demographic forecast of the Federal Service of State Statistics of Russia, the migration outflow of the population from the Irkutsk region will remain at the level of 5-7 thousand people per year. Hopes to turn the negative migration balance into a positive one were not made true. Positive dynamics is noted only in the city of Irkutsk. The administrative center, thanks to the universities, attracts young people who stay in the city after graduation as they see here more prospects for their development. In 2017, the population of Irkutsk was 629,980 people; in $2016-623,424$ people [3]. This is one of the cities in the region where the population does not decrease. The popularity of life in the northern areas of the Irkutsk region (Bodaibo, Bratsk, Ust-Kut, and Ust-Ilimsk) is falling due to a lack of desire to live in harsh climatic conditions with poorly developed infrastructure, rising consumer prices, low level of healthcare, and in the absence of the educational prospects. In 2016, 64,235 people left the Irkutsk region, and 58,000 people came mainly from the CIS countries (Uzbekistan, Kyrgyzstan, Tajikistan, and Ukraine) [4]. It should be noted that if the region is left mostly by the people with higher education, those who arrive here in the best case have secondary or vocational education. Over the past 15 years, the labor migration to Russia shows a quantitative growth, an average of more than 6 million people annually arriving to the country.

As a result of 2016, the demographic situation in the region was characterized by a natural increase $(+3.6$ thousand people), a population migration loss (-7.1 thousand people) and an increase in the level of life expectancy. In 2016, it was 68.2 years, and in 2015 - 67.4 years. In 2016, 35579 people were born in the region that is 1325 less than in 2015. This pattern can be observed throughout Russia. According to the data of the Federal State Statistics Service, in 2017, 1.69 million babies were born that is 203 thousand less than last year.

In 2016, the organizations of all forms of ownership commissioned 881.5 thousand square meters of housing, which amounted to $95.5 \%$ to the level of 2015 .

The retail trade turnover amounted to 298.9 billion rubles in 2016 and decreased by $5.7 \%$ in comparable prices to 2015 . For 2016, the consumer prices for goods and services grew by $6.7 \%$, including for foodstuffs - by $4.7 \%$, non-food products - by $10.1 \%$, services - by $3.1 \%$.

Lately, the industrial production of Buryatia has shown the worst results in Russia. The index of industry for 9 months of 2017 amounted to $88.1 \%$ to the same indicator of the previous year [5]. Other depressive regions with the closest indicators are the Chukotka Autonomy with the Industrial Production Index of 93\%, and Kalmykia - 95\%. The remaining constituent entities of the Russian Federation surpassed the same period of the last year. The 
processing industries became the main point of failures in Buryatia $-83.7 \%$. The volume of production fell down by almost 17\%, the public debt of Buryatia in 2017 increased by 1.1 billion rubles in comparison with the previous year and amounted to 14.1 billion rubles [6]. In connection with the financing gap, the aggregate volume of the state debt of the Republic and the obligations of municipalities increased by 1.1 billion rubles in comparison with the previous year, and on January 1, 2018 amounted to 14.1 billion, which is the limit of exceeding 50\% of the volume of tax- and non-tax revenues. In 2017, the consolidated budget of the Republic received 56 billion rubles, while the budget deficit is 2.3 billion rubles. The revenues are 38.7 billion rubles, of which taxes and non-tax revenues of the Republic itself are 22.4 billion rubles. The gratuitous income may decrease by 4 billion rubles at once and reach 16.24 billion rubles, and by 2019 the debt will be $82.3 \%$ of own revenues of the Republic. The service of the national debt will also increase rapidly. Next year, the cost of loans will be 900 million, and by 2019 - 1.5 billion rubles. For 2017-2018, expenses for the debts servicing will grow by $40 \%$.

In 2015, the migration loss in Buryatia was 2006 people, in 2016 - 3213 people. The retail trade turnover amounted to $170,327.6$ million rubles and decreased by $1.3 \%$, compared to January-December 2016. In December 2017 compared to December 2016, the index of consumer prices and tariffs for goods and services to the population reached $102.1 \%$. Food products in December 2017 (by December 2016) went up by $0.1 \%$, non-foods rose by $4.1 \%$, the cost of services to the population increased by $2.9 \%$. The average monthly wage accrued in 2017, according to preliminary data, was $33,400.3$ rubles. The real wage, calculated taking into account the consumer price index, was $106.1 \%$ to the level of November 2016.

In 2017, the outflow of the population from the Far East increased. On January 1, 2015, the population of the Far Eastern Federal District was 6,211,021 people, as of January 1, 2016 - 6,194,696 people (minus 16,052 inhabitants per year), as of January 1, $2017-6,182,679$ people (minus 12,290 residents per year). The data for January 1, 2018 is not yet available. In 2016, as the Minister for the Development of the Far East Aleksandr Galushka reported, the Far East managed to attract 1.325 trillion rubles of investments. Meanwhile, in the rhetoric of the officials developing the Far East, 2017 looked rich in results. The amount of attracted direct investments, according to the data of the Ministry of Economic Development, has grown to 3.7 trillion rubles. Only free "Far Eastern hectares", designed to encourage the Far East residents to stay in the region, and non-far-east residents to come to the region, were issued of more than 34 thousand. All macroeconomic indicators seem to be growing. Unfortunately, the government's efforts affect the tendency of the outflow of the population from the Far East in the most unexpected way.

In this study, we used statistical methods, generic scientific methods of cognition, such as induction and deduction, moving from abstract to concrete, analysis and synthesis, explanation, analogy, and comparison.

The dialectical method allowed us considering some of the reasons that generate crisis phenomena in the economy, as well as to determine the specifics of the main directions of the contemporary economic development.

The priority attention was given to the establishment of the cause-effect relationships.

\section{Results}

The main task of the state policy of the economic development of Eastern Siberia and the Far East is to improve the legislative framework for the implementation of public-private partnerships that will allow attracting both Russian and foreign investors. Along with this, it is required to implement a whole range of economic policy measures, stimulate investment and innovation activities of companies, as well as create conditions for stimulating and attracting highly skilled workforce to the region. 


\section{Discussion}

The diverse resources of Eastern Siberia and the Far East are not yet fully in use today. The difficult economic situation of reserves, foresters, the issues of preserving national natural parks require an early solution. It is necessary to mention some more actual issues which require decisions:

- economic underdevelopment of the territory;

- a weak degree of urbanization and infrastructure development;

- extreme climatic conditions of the winter period;

- weak development of the material base of tourism;

- special interest from different states towards pristine, sparsely populated territories;

- the growing popularity of the environmental tourism (a program of tourist routes is needed that will be carefully thought out and will not negatively affect the changes in the natural landscape, that is important for future generations).

\section{Conclusion}

The analysis of the indices of the industrial growth shows that the Russian economy is moving towards state monopolization and enlargement. The growth of the economic indicators is of the specific points' type and does not affect the social well-being of the residents of the regions examined in the paper, as a whole. There are some state corporations in which everything is Okay in terms of wages, investment, industry growth, but the rest of the economy is stagnating. The industrial indices depend, in fact, on the work of the state corporations, which continue implementing large investment projects in these regions. These corporations take all significant government orders preventing normal competition between other enterprises. Only in large and resource production companies, salaries increase outpacing the inflation rate. All this negatively affects the medium-sized business, entrepreneurial activity, and the living standard of the population. Pensions are indexed below inflation, interest rates in banks are falling that reduces income from deposits, income from renting is also decreasing, there is an increase in the tax burden, and consumer price growth. The total amount of incomes of the population is formed by all these indicators, and it is declining. For example, the Federal Tax Service entered the list of the agencies that exceeded the revenue plan collected to the Russian budget in 2017. Last year this agency collected to the Russian Federation budget 9,161.87 billion rubles, an increase from the planned volume amounted to +454.06 billion rubles.

There are mutually exclusive things: with the growth of investments in these regions, they did not manage to reach a positive migration balance.

\section{References}

1. Report of the Governor of Irkutsk region for 2016 (https://irkutsk.news/novosti/201706-29/23227-otchet-gubernatora-2016-v-cifrah-chem-obogatilas-irkutskajaoblast.html, 2017)

2. BaikalInfo, The Irkutsk region is ahead of the all-Russian level in terms of basic economic indicators (http://baikal-info.ru/irkutskaya-oblast-operezhaetobshcherossiyskiy-uroven-po-osnovnym-ekonomicheskim-pokazatelyam)

3. Information on the number and demographic characteristics of the population of the Irkutsk region (http://irkobl.ru/region/demografy)

4. The territorial body of the Federal State Statistics Service for the Irkutsk region (http://irkutskstat.gks.ru) 
5. The crisis budget of Buryatia - 2017: only 5\% for the development of the economy (https://www.baikal-daily.ru/news/15/221821, 2016)

6. Territorial Body of the Federal State Statistics Service for the Republic of Buryatia, Buryatia in figures: statistical digest (Ulan-Ude, 2016)

7. G. I. Galaziy, Baikal in questions and answers (Irkutsk, 2017)

8. A. N. Asaul, Investment attractiveness of the region: monograph (SPbGASU, St. Petersburg, 2008)

9. L. G. Rudykh, Izvestiya Vuzov. Investments. Building. Real Estate, 2 (17), 89-92 (2016).

10. Results of the 5th annual rating of the investment attractiveness of the Russian region, 13 (2017)

11. M. O. Azatyan, Materials of the VII international scientific conference on Economics, Management, Finance, 10-14 (2017)

12. A. V. Bogoviz, S. V. Lobova, Y. A. Bugai, Advances in Intelligent Systems and Computing, 622, 30-36 (2018)

13. K. Khubiev, Russian economy in the context of globalization (2013)

14. M. Rochlitz, Corporate raiding and the role of the state in Russia, 89-114 (2014)

15. M. Mazzucato, L. R. Wray, Working Paper, 837 (2015) 